\title{
Energy Efficient Manufacturing of Nanocellulose by Chemo- and Bio-Mechanical Processes: A Review
}

\author{
Ashok K. Bharimalla1, Suresh P. Deshmukh ${ }^{2}$, Prashant G. Patil ${ }^{1}$, \\ Nadanathangam Vigneshwaran ${ }^{1^{*}}$ \\ ${ }^{1}$ ICAR-Central Institute for Research on Cotton Technology, Mumbai, India \\ ${ }^{2}$ Department of General Engineering, Institute of Chemical Technology, Mumbai, India \\ Email: *Vigneshwaran.N@icar.gov.in, "nvw75@yahoo.com
}

Received 27 November 2015; accepted 26 December 2015; published 29 December 2015

Copyright (C) 2015 by authors and Scientific Research Publishing Inc.

This work is licensed under the Creative Commons Attribution International License (CC BY).

http://creativecommons.org/licenses/by/4.0/

(c) (i) Open Access

\begin{abstract}
Nanocellulose is a new-age material derived from cellulosic biomass and has large specific surface area, high modulus and highly hydrophilic in nature. It comprises of two structural forms viz., nanofibrillated cellulose (NFC) and nanocrystalline cellulose (NCC). This review provides a critical overview of the recent methods of bio- and chemo-mechanical processes for production of nanocellulose, their energy requirements and their functional properties. More than a dozen of pilot plants/commercial plants are under operation mostly in the developed countries, trying to exploit the potential of nanocellulose as reinforcing agent in paper, films, concrete, rubber, polymer films and so on. The utilization of nanocellulose is restricted mainly due to initial investment involved, high production cost and lack of toxicological information. This review focuses on the current trend and exploration of energy efficient and environment-friendly mechanical methods using pretreatments (both chemical and biological), their feasibility in scaling up and the future scope for expansion of nanocellulose application in diverse fields without impacting the environment. In addition, a nanocellulose quality index is derived to act as a guide for application based screening of nanocellulose production protocols.
\end{abstract}

\section{Keywords}

Biodegradable, Energy Conservation, Mechanical Process, Nanocellulose, Pretreatment

\section{Introduction}

In the last two decades, several reviews have been published on nanocellulose [1]-[5], preparation by TEMPO

${ }^{*}$ Corresponding author.

How to cite this paper: Bharimalla, A.K., Deshmukh, S.P., Patil, P.G. and Vigneshwaran, N. (2015) Energy Efficient Manufacturing of Nanocellulose by Chemo- and Bio-Mechanical Processes: A Review. World Journal of Nano Science and Engineering, 5, 204-212. http://dx.doi.org/10.4236/wjnse.2015.54021 
(2,2,6,6-tetramethylpiperidine-1-oxyl radical)-mediated oxidation [6], various mechanical processes [7] and their potential applications in composites [8]-[10] and liquid crystal displays [11]. Due to applications envisaged in various areas and their future growth predictions, book chapters [12] [13] books [14] [15] have been exclusively dedicated for the science and technology on nanocellulose. In addition, nanocellulose patents' trends are also well documented recently [16] [17]. Till now, the huge energy requirement for production of nanocellulose hampers their entry into the wider commercial market. Hence, in this review, our main focus is to discuss the advances in manufacturing processes for production of nanocellulose by chemo- and bio-mechanical means; in which the efficacy of chemical and biological pretreatments and their impact on subsequent mechanical treatments are discussed in detail.

\section{Cellullose}

Cellulose is a natural biopolymer made up of linear chain of several hundred to over ten thousand $\beta(1 \rightarrow 4)$ linked D-glucose, having the formula $\left(\mathrm{C}_{6} \mathrm{H}_{10} \mathrm{O}_{5}\right) \mathrm{n}$ and stabilized by intermolecular hydrogen bonds. The French chemist Anselme Payen in 1838, described fibrous solid material present in various plant tissues and determined its molecular formula to be $\mathrm{C}_{6} \mathrm{H}_{10} \mathrm{O}_{5}$ by elemental analysis [18]; and, the term "cellulose" was first used in 1939 in a report of the French academy on the work of Payen. It is a crystalline structural polysaccharide and the most abundant form of living terrestrial biomass available on Earth. Formed by the repeated connection of D-glucose building blocks, the highly functionalized, linear stiff-chain homopolymer is characterized by its hydrophilicity, chirality, biodegradability, broad chemical modifying capacity, and its formation of versatile semi crystalline fiber morphologies [19]. This review focused on new frontiers, including environmentally friendly cellulose fiber technologies, bacterial cellulose biomaterials, and in vitro syntheses of cellulose together with future aims, strategies, and perspectives of cellulose research and its applications. The polymorphs of cellulose (I, II, III and IV) and their preparation protocols are discussed in detail in a book chapter in 2007 [20]. As per this reference, though cellulose has cellobiose as monomer, the ideal shape for cellulose does not have a two-fold structure and that a range of shapes should occur.

The present three kinds of hydroxyl groups within an anhydroglucose unit in a cellulose molecule exhibit different polarities, which contribute to formation of various kinds of inter- and intra-molecular hydrogen bonds among secondary "-OH" at the C-2, secondary "-OH" at the C-3 and primary "-OH" at the C-6 position. In addition, all the hydroxyl groups are bonded to a glucopyranose ring equatorially. This causes appearance of hydrophilic site parallel to the ring plane. On the contrary, the "-CH" groups are bonded to a glucopyranose ring axially, causing hydrophobic site perpendicular to the ring. These effects lead to formation of hydrogen bonds in parallel direction to a glucopyranose ring, and to van der Waals interaction perpendicular to the ring [21].

Cellulose occurs in almost the purest form in cotton fibers, while in wood and various parts of plants, it is found in combination with other materials, mainly lignin and hemicelluloses. Cotton fibers are of great interest as they lack lignin, which minimizes number of processes during manufacturing of nanocellulose. Cellulose is also produced by bacteria, algae, fungi and tunicates. Figure 1 shows the schematic representation of structural arrangement of cellulose microfibrils in cottonfibers.

\section{Nanocellulose}

Nanocellulose represents a new family of nanomaterials that appear to have very broad applications in a variety of materials related domains where physical characteristics such as strength, weight, rheology, optical properties and the like can be affected in a very positive manner (TAPPI, 2011). Acronyms commonly used to denote nanocellulose include cellulose nanocrystals (CNC), nanocrystalline cellulose (NCC), cellulose nanoparticles (CNP), microfibrillated cellulose (MFC) and nanofibrillated cellulose (NFC). A recommendation on the preliminary terminology framework for nanocellulose was presented at an initial TAPPI's workshop held in Arlington on $9^{\text {th }}$ June 2011 as given in Figure 2. In this classification, cellulose nanofibrils and cellulose microfibril are classified separately that we feel is confusing since it is very much difficult to differentiate these two materials by virtue of their overlapping in properties. While few researchers classify bacterial cellulose as a type of nanocellulose, it is beyond the scope of this review and hence, not included here. Hence, in this review, nanocellulose is classified only as two groups viz., Nanocrystalline cellulose (NCC) having low aspect ratio $(<100)$ and Nanofibrillated cellulose (NFC) having high aspect ratio $(>100)$ and taken up for further discussion. 


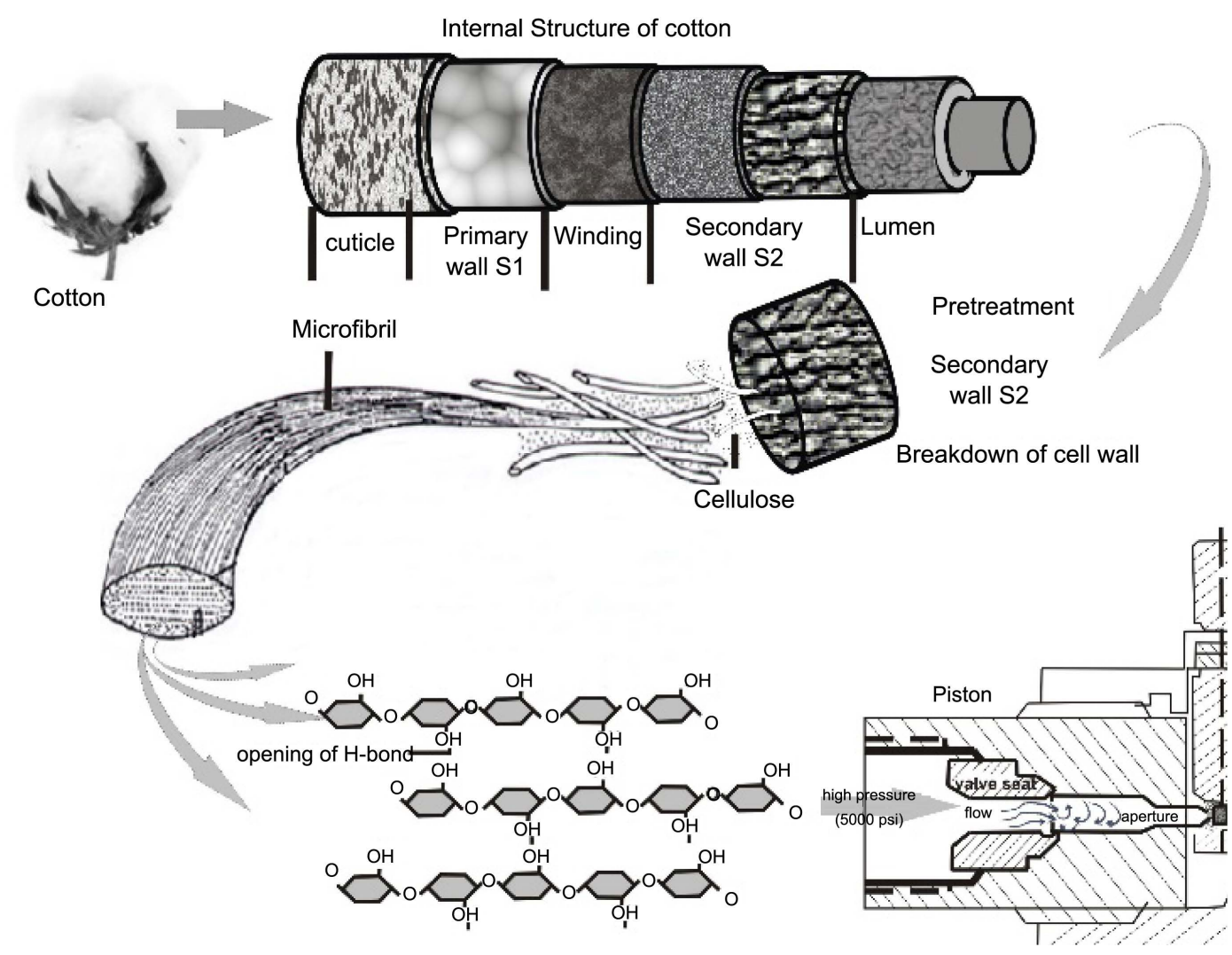

Figure 1. Schematic representation of structural arrangement of cellulose microfibrils in cottonfibers.

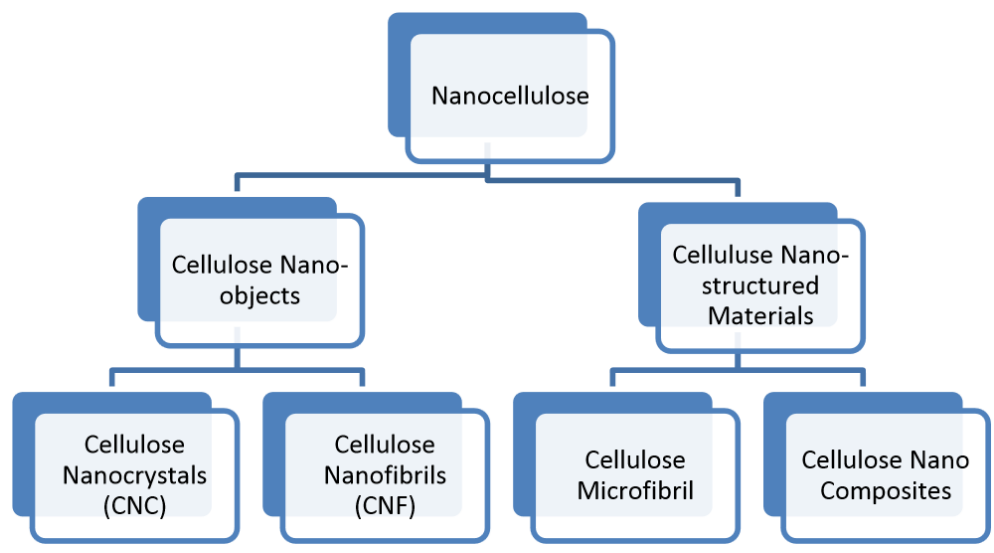

Figure 2. Naming hierarchy of nanocellulose as per the TAPPI's workshop held in Arlington on $9^{\text {th }}$ June 2011.

\subsection{Structural Properties of Nanocellulose}

The nanocellulose is the smallest structural part of the cellulosic biomass of various organisms. While NFC is generally produced by mechanical process, NCC is by concentrated acid hydrolysis. Hence, the NFC is more in amorphous nature when compared to NCC. These basic structural differences lead to different types of application for NFC and NCC.

The determination of stiffness by theoretical and experimental means has shown that native cellulose (cellulose I) has a Young's modulus of $167.5 \mathrm{GPa}$ and that of regenerated cellulose (cellulose II) is $162.1 \mathrm{GPa}$ [22]. Using atomic force microscopy (AFM), various researchers evaluated the elastic modulus of both NCC and NFC. Self-standing TEMPO oxidized cellulose nanofibres are transparent and flexible, with high tensile 
strengths of 200 - $300 \mathrm{MPa}$ and elastic moduli of 6 - 7 GPa [6]. The high strength of nanofibrillar cellulose combined with its potential economic advantages offers the opportunity to make lighter and strong materials with greater durability. Indeed, because of these properties nanofibres have attracted a lot of research effort in different disciplines and continues to be a subject of its utility in everyday materials such as paints, packaging, cosmetic bases, pigments, food modifiers, sensor applications, biomedical sciences and composites.

\subsection{Energy Requirement for Manufacturing of Nanocellulose}

For nanocellulose production, the inter-fibrillar hydrogen bonding (of cellulose) energy has to be overcome. Since, more than one type of hydrogen bond is present, a range of values need to be considered to quantify the hydrogen bond strength; and, it ranges between 19 and $21 \mathrm{MJ} / \mathrm{kg}$ mol [23]. Traditionally, mechanical homogenization process is used in large-scale production of nanocellulose that leads to huge energy consumption to the tune of 20,000 to 30,000 kWh per tonne [8]; and the required energy is 4 - 5 times that of the stored energy of that cellulosic biomass [24]. In one of the earliest patent [25], NFC was produced by passing a liquid suspension of cellulose through small diameter orifice in which the suspension is subjected to a pressure drop of at least 3000 psi and a high velocity shearing action followed by a high velocity decelerating impact, with repeated passes (11 numbers) till formation stable suspension. The production of cellulose nanofibrils from a bleached eucalyptus pulp ( $2 \%$ consistency) using a commercial stone grinder (SuperMassColliderTM) required the energy in the order of 5 - $30 \mathrm{kWh}$ per $\mathrm{kg}$ [26]. To reduce the energy consumption, various types of pretreatments (chemical and biological) are being evaluated that results in drastic reduction of energy consumption less than $1000 \mathrm{kWh}$ per tonne.

Energy requirement by mechanical pretreatment to produce MFC films with maximum obtainable properties for each processing method, the total energy required was approximately $9180 \mathrm{~kJ} / \mathrm{kg}$ for the microfluidizer with pretreatment, $9090 \mathrm{~kJ} / \mathrm{kg}$ for the grinder with pretreatment, and $5580 \mathrm{~kJ} / \mathrm{kg}$ for the grinder without pretreatment and $31,520 \mathrm{~kJ} / \mathrm{kg}$ for the homogenizer with pretreatment. Here, the pretreatment was a mechanical beating process (processed in a valley beater) [27].

\subsection{Reduction in Energy Consumption by Chemical Pretreatment}

The literature review on the effect of various chemical pretreatments on energy conservation or requirement for nanocellulose production is listed in the Table 1 . Depending on the process and their analyses, the energy conservation/requirement are listed in the references. The energy calculated focused only on the actual energy required for mechanical comminution process without including the energy required during chemical pretreatments. Hence, a fair comparison of energy conservation is not possible.

Within the framework of EU-FP7 INNOBITE project, the Spanish applied research institute Tecnalia Research \& Innovation and Ecopulp Finland Oy, a SME devoted to the production of shape moulded pulps out of waste paper, are developing a new method for converting waste paper into a new value-added material: newspaper-based nanocellulose [33]. The target is reducing the energy needed for the paper fibrillation process, for which a specialty pulp is generated via oxidation reactions. This chemical treatment converts the hydroxyl groups at the native cellulose fibres into carboxylate groups, thus creating anionic charges that will subsequently turn into repulsion forces within the internal structure of the fibres. Combining Ecopulp's industrial facilities and Tecnalia's know-how, such a specialty cellulose pulp has already been produced in mid-scale. So far, the energy requirement for complete paper fibrillation has been decreased to values of $2.1 \mathrm{kWh}$ per kilo of dry matter that equals the range of other extensively applied industrial treatments such as pulp refining.

\subsection{Reduction in Energy Consumption by Biological Pretreatment}

While chemical pretreatment results in substantial reduction of energy consumption, there erupts the problem of waste disposal and release of chemical pollutants into the environment. Also, depending on the nature of the chemical treatment, the surface chemistry of cellulose gets modified. To circumvent these problems, biological pretreatment shall be an ideal means of reducing energy consumption without creating chemical effluents.

The high hemicellulose content of the pulp decreases the cell wall cohesion of the fibers, making cell wall delamination easier. But, this alone was not sufficient to avoid blocking of the orifice in the homogenizer and to reduce energy consumption. Hence, small additions of the mono-component endoglucanases enzyme promoted cell wall delamination and prevented the blocking of homogenizer [34]. 
Table 1. Effect of chemical pretreatments on energy conservation/requirement during nanocellulose production.

\begin{tabular}{|c|c|c|c|c|c|}
\hline No. & Pretreatments & $\begin{array}{c}\text { Effect of } \\
\text { pretreatments }\end{array}$ & References & $\begin{array}{l}\text { Energy conservation } \\
\text { requirement }\end{array}$ & $\begin{array}{l}\text { Process \& } \\
\text { remarks }\end{array}$ \\
\hline 1 & $\begin{array}{l}\text { (a) Ozone at a charge level of at least about } \\
0.1 \mathrm{wt} / \mathrm{wt} \% \text {, based on the dry weight of the } \\
\text { cellulosic material for generating free } \\
\text { radicals in the slurry } \\
\text { (b) Cellulase enzyme at a concentration } \\
\text { from about } 0.1 \text { to about } 10 \text { lbs/ton based on } \\
\text { the dry weight of the cellulosic material } \\
\text { A combination of both (a) and (b) } \\
\text { mentioned above }\end{array}$ & $\begin{array}{l}\text { Partial } \\
\text { depolymerization } \\
\text { of cellulose }\end{array}$ & [28] & $\begin{array}{l}>2 \% \text { energy } \\
\text { conserved }\end{array}$ & Comminution processing \\
\hline 2 & $\begin{array}{l}\text { Organic (morpholine, piperidine or } \\
\text { mixtures) or inorganic (inorganic halide, an } \\
\text { inorganic hydroxide, or mixtures thereof) } \\
\text { swelling agent or a mixture thereof }\end{array}$ & Swelling of cellulose & [29] & $\begin{array}{l}1400 \mathrm{kWh} / \mathrm{t} \text { energy } \\
\text { required } \\
500 \mathrm{kWh} / \mathrm{t} \text { energy } \\
\text { required }\end{array}$ & $\begin{array}{l}\text { Comminution processing } \\
80 \% \text { nanocellulose } \\
\text { (defined as having an } \\
\text { average diameter of } \\
\text { less than } 30 \mathrm{~nm} \text { ) } \\
\text { 45\% of the material having } \\
\text { average } \\
\text { diameters less than } 30 \mathrm{~nm}\end{array}$ \\
\hline 3 & Carboxymethylation & $\begin{array}{l}\text { Increases the anionic } \\
\text { charges due to the } \\
\text { formation of carboxyl } \\
\text { groups in the surface }\end{array}$ & [30] & $\begin{array}{l}5500 \mathrm{kWh} / \mathrm{t} \text { without } \\
\text { pretreatment } \\
\text { (per pass through)- } \\
\text { Minimum of } 4 \text { passes } \\
2200 \mathrm{kWh} / \mathrm{t} \text { with } \\
\text { pretreatment } \\
\text { (per pass through)-4 } \\
\text { passes } \\
30000 \mathrm{~kW} / \mathrm{t} \text { (total) } \\
\text { without pretreatment }\end{array}$ & $\begin{array}{c}\text { Microfluidization process } \\
\text { Ultra-fine friction grinding }\end{array}$ \\
\hline 4 & $\begin{array}{l}\text { Carboxymethylation OR by irreversibly } \\
\text { attaching CMC onto cellulose fibres }\end{array}$ & $\begin{array}{l}\text { Increases the anionic } \\
\text { charges due to the } \\
\text { formation of carboxyl } \\
\text { groups in the surface }\end{array}$ & [31] & $500-2300 \mathrm{kWh} / \mathrm{t}$ & Microfluidization process \\
\hline 5 & $\begin{array}{l}\text { Acid like sulfur dioxide, sulfurous acid, } \\
\text { sulfur trioxide, sulfuric acid, lignosulfonic } \\
\text { acid \& their combinations or enzyme }\end{array}$ & Hydrolysis & [32] & $<1000 \mathrm{kWh} / \mathrm{t}$ & Mechanical treatment \\
\hline
\end{tabular}

The bio-mechanical process overcomes the high energy requirement to a certain extent; however, the use of cellulose hydrolyzing enzymes also has a negative impact on the molecular weight and the chain length of the isolated nanocellulose [35]. Hence, pretreatment with the fungus secreting hydrogen bond-specific enzymes was tested to produce nanocellulose with mechanical strength marginally higher to that of those isolated via a conventional mechanical process since the bio-pretreatment produced nanocellulose had higher aspect ratio.

In spite of various protocols claiming energy reduction due to enzyme/biological pretreatments, energy calculations are not available for comparison of actual energy saving. In our lab, we are working with the cellulase enzyme pretreatments of various cellulosic biomasses (cotton linter pulp, soft wood pulp, hard wood pulp and bagasse) before proceeding for mechanical treatments by refiner and microfluidization for production of nanocellulose (both NCC and NFC). In case of NCC production from cellulose powder, a minimum of 10 passes are required in the high pressure homogenizer OR microfluidizer to reach the desired size range below $100 \mathrm{~nm}$. But, in case of enzyme (cellulase) pretreatment, with 5 passes itself, we could achieve the desired size range; and hence, a 50\% reduction in energy consumption can be claimed. But, the problem faced was the time \& process required for the removal of enzyme after pretreatment; and the same needs to be quantified in terms of energy requirement. In case of NFC production from cellulosic pulp, it is not possible to treat with high pressure homogenizer OR microfluidizer without enzyme pretreatment. If a mechanical pretreatment like beating/refining is imparted to make it amenable for homogenization/microfluidization, then the energy required in case of both mechanical pretreatment and enzyme pretreatment were same. The energy requirement in enzyme pretreatment (including heating and stirring) was high enough to make them equivalent to that of mechanical pretreatment. 


\subsection{Comparison of Energy Consumption in Chemical and Biological Pretreatments}

Figure 3 shows the comparison of three different processes for manufacturing nanocellulose (mechanical, chemo-mechanical and bio-mechanical) in terms of productivity, energy efficiency and ease of handling in radar chart. All three protocols display their own strength and weaknesses. The mechanical process shows its strength in productivity, chemo-mechanical process in ease of handling and bio-mechanical process in energy efficiency. In weaknesses, only bio-mechanical process suffers both in terms of productivity and ease of handling while mechanical process suffers in energy efficiency. For selection among these three different protocols during commercial production, apart from the above said three parameters, quality of the nanocellulose needs to be considered based on the required area of application. We have formulated a "Nanocellulose Quality Index" to choose the nanocellulose for desired application (Figure 4). The two influential (on final product) quality para-

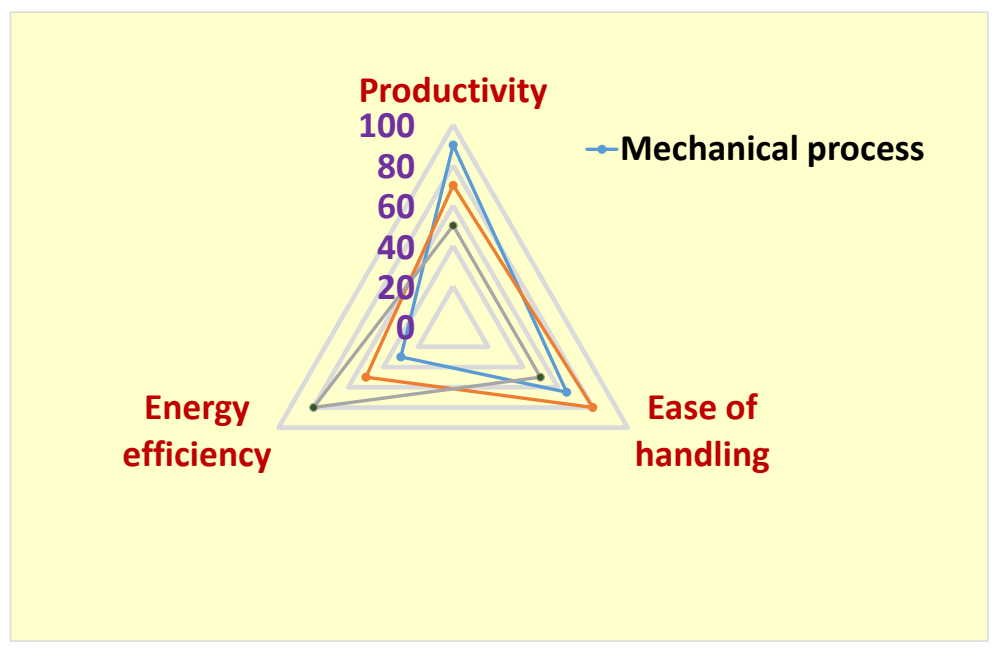

Figure 3. Comparison of three different processes for manufacturing nanocellulose in terms of productivity, energy efficience and ease of handling. Scale from 0 to 100 represents benefit/advantage in terms of percentage.

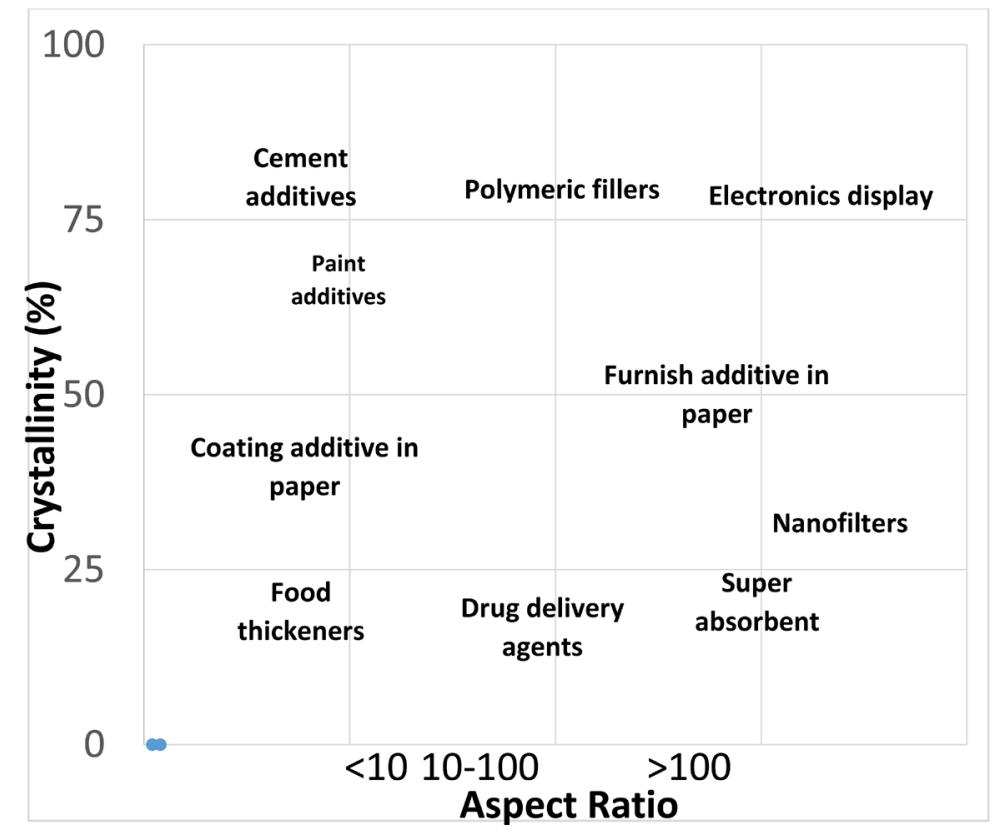

Figure 4. Nanocellulose Quality Index based on aspect ratio and crystallinity for various applications. 
meters, aspect ratio and crystallinity are included in arriving at the index. While crystallinity improves strength and modifies rheological attributes, aspect ratio acts towards web formation in films, displays and improves strength. Based on their combined values, their suitability of applications can be determined as suggested in the Figure 4.

\section{Outlook}

In spite of various reports claiming reduction in energy consumption in nanocellulose manufacturing due to pretreatments, a holistic approach is required to include the energy equivalents of various axillaries and other processes involved during such pretreatments. Energy consumption in terms of chemicals/enzyme equivalence, time required for pretreatments, quality of output subjected to pretreatments needs to be evaluated and used for comparison. Such a measure is possible in pilot plants/commercial plants of nanocellulose production. The suggested nanocellulose quality index will act as a guide for application based screening of nanocellulose production protocols.

\section{Acknowledgements}

The authors are thankful to Dr. S. K. Chattopadhyay and Dr. Sujata Saxena of ICAR-Central Institute for Research on Cotton Technology, Mumbai, India for their kind suggestions and support for this work. This work was financially supported by the National Agricultural Innovation Project, Indian Council of Agricultural Research through its sub-project entitled “ZTM-BPD Unit of CIRCOT”.

\section{References}

[1] Lavoine, N., Desloges, I., Dufresne, A. and Bras, J. (2012) Microfibrillated Cellulose-Its Barrier Properties and Applications in Cellulosic Materials: A Review. Carbohydrate Polymers, 90, 735-764. http://dx.doi.org/10.1016/j.carbpol.2012.05.026

[2] Giri, J. and Adhikari, R. (2013) A Brief Review on Extraction of Nanocellulose and Its Application. BIBECHANA, 9, 7.

[3] Rebouillat, S. and Pla, F. (2013) State of the Art Manufacturing and Engineering of Nanocellulose: A Review of Available Data and Industrial Applications. Journal of Biomaterials and Nanobiotechnology, 4, 24. http://dx.doi.org/10.4236/jbnb.2013.42022

[4] Dufresne, A. (2013) Nanocellulose: A New Ageless Bionanomaterial. Materials Today, 16, 220-227. http://dx.doi.org/10.1016/j.mattod.2013.06.004

[5] Klemm, D., Kramer, F., Moritz, S., Lindstrom, T., Ankerfors, M., Gray, D., et al. (2011) Nanocelluloses: A New Family of Nature-Based Materials. Angewandte Chemie International Edition, 50, 5438-5466. http://dx.doi.org/10.1002/anie.201001273

[6] Isogai, A., Saito, T. and Fukuzumi, H. (2011) TEMPO-Oxidized Cellulose Nanofibers. Nanoscale, 3, 71-85. http://dx.doi.org/10.1039/C0NR00583E

[7] Abdul Khalil, H.P.S., Davoudpour, Y., Islam, M.N., Mustapha, A., Sudesh, K., Dungani, R., et al. (2014) Production and Modification of Nanofibrillated Cellulose Using Various Mechanical Processes: A Review. Carbohydrate Polymers, 99, 649-665. http://dx.doi.org/10.1016/j.carbpol.2013.08.069

[8] Siró, I. and Plackett, D. (2010) Microfibrillated Cellulose and New Nanocomposite Materials: A Review. Cellulose, 17, 459-494. http://dx.doi.org/10.1007/s10570-010-9405-y

[9] Abdul Khalil, H.P.S., Bhat, A.H. and Ireana Yusra, A.F. (2012) Green Composites from Sustainable Cellulose Nanofibrils: A Review. Carbohydrate Polymers, 87, 963-979. http://dx.doi.org/10.1016/j.carbpol.2011.08.078

[10] Azizi Samir, M.A., Alloin, F. and Dufresne, A. (2005) Review of Recent Research into Cellulosic Whiskers, Their Properties and Their Application in Nanocomposite Field. Biomacromolecules, 6, 612-626.

http://dx.doi.org/10.1021/bm0493685

[11] Lagerwall, J.P.F., Schutz, C., Salajkova, M., Noh, J., Park, J.H., Scalia, G., et al. (2014) Cellulose Nanocrystal-Based Materials: From Liquid Crystal Self-Assembly and Glass Formation to Multifunctional Thin Films. NPG Asia Materials, 6, e80. http://dx.doi.org/10.1038/am.2013.69

[12] Aspler, J., Bouchard, J., Hamad, W., Berry, R., Beck, S., Drolet, F., et al. (2013) Review of Nanocellulosic Products and Their Applications. In: Dufresne, A., Thomas, S. and Pothen, L.A., Eds., Biopolymer Nanocomposites: Processing, Properties, and Applications, John Wiley \& Sons, Inc., Hoboken, 461-508. 
http://dx.doi.org/10.1002/9781118609958.ch20

[13] Spence, K., Habibi, Y. and Dufresne, A. (2011) Nanocellulose-Based Composites. In: Kalia, S., Kaith, B.S. and Kaur, I., Eds., Cellulose Fibers: Bio- and Nano-Polymer Composites, Springer, Berlin, 179-213. http://dx.doi.org/10.1007/978-3-642-17370-7_7

[14] Dufresne, A. (2012) Nanocellulose: From Nature to High Performance Tailored Materials. De Gruyter, Berlin. http://dx.doi.org/10.1515/9783110254600

[15] Surhone, L.M., Tennoe, M.T. and Henssonow, S.F. (2011) Nanocellulose. Betascript Publishing, Beau-Bassin.

[16] Charreau, H., Foresti, M.L. and Vazquez, A. (2013) Nanocellulose Patents Trends: A Comprehensive Review on Patents on Cellulose Nanocrystals, Microfibrillated and Bacterial Cellulose. Recent Patents on Nanotechnology, 7, 56-80. http://dx.doi.org/10.2174/187221013804484854

[17] Duran, N., Lemes, A.P. and Seabra, A.B. (2012) Review of Cellulose Nanocrystals Patents: Preparation, Composites and General Applications. Recent Patents on Nanotechnology, 6, 16-28. http://dx.doi.org/10.2174/187221012798109255

[18] Payen, A. (1838) Mémoire sur la composition du tissu propre des plantes et du ligneux. (Memoir on the composition of the tissue of plants and of woody [material]). Comptes Rendus Hebdomadaires des Séances de l'Académie des Sciences, $7,7$.

[19] Klemm, D., Heublein, B., Fink, H.P. and Bohn, A. (2005) Cellulose: Fascinating Biopolymer and Sustainable Raw Material. Angewandte Chemie International Edition, 44, 3358-3393. http://dx.doi.org/10.1002/anie.200460587

[20] French, A. and Johnson, G. (2007) Cellulose Shapes. In: Brown Jr., R.M. and Saxena, I., Eds., Cellulose: Molecular and Structural Biology, Springer, Dordrecht, 257-284. http://dx.doi.org/10.1007/978-1-4020-5380-1 15

[21] Kondo, T. (2007) Nematic Ordered Cellulose: Its Structure and Properties. In: Brown Jr., R.M. and Saxena, I., Eds., Cellulose: Molecular and Structural Biology, Springer, Dordrecht, 285-305. http://dx.doi.org/10.1007/978-1-4020-5380-1_16

[22] Tashiro, K. and Kobayashi, M. (1991) Theoretical Evaluation of Three-Dimensional Elastic Constants of Native and Regenerated Celluloses: Role of Hydrogen Bonds. Polymer, 32, 1516-1526. http://dx.doi.org/10.1016/0032-3861(91)90435-L

[23] Nissan, A.H., Byrd, V.L., Batten, G.L. and Ogden, R.W. (1985) Paper as an H-Bond Dominated Solid in the Elastic and Plastic Regimes. Tappi Journal, 68, 118-124.

[24] Zhu, J.Y., Sabo, R. and Luo, X. (2011) Integrated Production of Nano-Fibrillated Cellulose and Cellulosic Biofuel (Ethanol) by Enzymatic Fractionation of Wood Fibers. Green Chemistry, 13, 1339-1344. http://dx.doi.org/10.1039/c1gc15103g

[25] Turbak, A.F., Snyder, F.W. and Sandberg, K.R. (1983) Microfibrillated Cellulose. Patent No. US 4374702 A.

[26] Wang, Q.Q., Zhu, J.Y., Gleisner, R., Kuster, T.A., Baxa, U. and McNeil, S.E. (2012) Morphological Development of Cellulose Fibrils of a Bleached Eucalyptus Pulp by Mechanical Fibrillation. Cellulose, 19, 1631-1643. http://dx.doi.org/10.1007/s10570-012-9745-X

[27] Spence, K., Venditti, R., Rojas, O., Habibi, Y. and Pawlak, J. (2011) A Comparative Study of Energy Consumption and Physical Properties of Microfibrillated Cellulose Produced by Different Processing Methods. Cellulose, 18, 10971111. http://dx.doi.org/10.1007/s10570-011-9533-z

[28] Bilodeau, M.A. and Paradis, M.A. (2013) Energy Efficient Process for Preparing Nanocellulose Fibers. Patent No. EP 2861799 A1.

[29] Graveson, I. (2014) Low Energy Method for the Preparation of Non-Derivatized Nanocellulose. Patent No. WO 2014009517 A1.

[30] Taipale, T., Österberg, M., Nykänen, A., Ruokolainen, J. and Laine, J. (2010) Effect of Microfibrillated Cellulose and Fines on the Drainage of Kraft Pulp Suspension and Paper Strength. Cellulose, 17, 1005-1020. http://dx.doi.org/10.1007/s10570-010-9431-9

[31] Ankerfors, M. (2012) Microfibrillated Cellulose: Energy Efficient Preparation Techniques and Key Properties. Licentiate Thesis, KTH Royal Institute of Technology, Stockholm, 49.

[32] Nelson, K., Retsina, T., Pylkkanen, V. and O’Connor, R. (2014) Processes and Apparatus for Producing Nanocellulose, and Compositions and Products Produced Therefrom. Patent No. US 20140154757 A1.

[33] Tejado, A. (2013) Review Series 1-Biorefinery and Microfibrillated Cellulose. 1st INNOBITE Workshop, INNOBITEWP8-DEL-D813-CIMV-20140314-v02doc.

[34] Pääkkö, M., Ankerfors, M., Kosonen, H., Nykänen, A., Ahola, S., Österberg, M., et al. (2007) Enzymatic Hydrolysis Combined with Mechanical Shearing and High-Pressure Homogenization for Nanoscale Cellulose Fibrils and Strong 
Gels. Biomacromolecules, 8, 1934-1941. http://dx.doi.org/10.1021/bm061215p

[35] Janardhnan, S. and Sain, M. (2011) Targeted Disruption of Hydroxyl Chemistry and Crystallinity in Natural Fibers for the Isolation of Cellulose Nano-Fibers via Enzymatic Treatment. BioResources, 6, 1242-1250. 